\section{JURNAL ABDIMAS

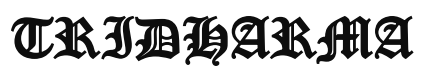 AtA}

P-ISSN 2615-6849, E-ISSN 2716-070X

Jurnal ABDIMAS Vol. 2,No.3, Agustus 2021,Hal(86-95)

@ Prodi Manajemen Fakultas Ekonomi Universitas Pamulang

Email: abdimasjurnal.unpam@gmail.com Telp: (021) 741-2566

\title{
PENYULUHAN PENGELOLAAN KEUANGAN SEDERHANA DAN PELATIHAN MANAJEMEN ORGANISASI PADA REMAJA DI YAYASAN AL KAMILAH BOJONGSARI SERUA DEPOK - JAWA BARAT
}

\author{
Ananda Hadistia ${ }^{1}$, Muhamad Faozan Afandi ${ }^{2}$, Indri Karisma ${ }^{3}$, \\ Ardi Bachtiar ${ }^{4}$, Shela Indah Savitri ${ }^{5}$ \\ Dosen Manajemen Fakultas Ekonomi Universitas Pamulang \\ Email : dosen02397@unpam.ac.id, dosen02279@unpam.ac.id, dosen02474@unpam.ac.id, \\ dosen02475@unpam.ac.id, dosen02583@unpam.ac.id
}

\begin{abstract}
The purpose of this community service activity is to implement one of the Tri Dharma of Higher Education. In addition, it is to foster creativity, independence and be able to manage themselves and finance well and be more focused for teenagers at the Al-Kamilah Foundation Depok by introducing simple financial management methods and conducting organizational management training, especially leadership and communication. The method of implementing Community Service activities used is counseling, question and answer, discussion and also sharing experiences. The technique in implementing Community Service activities used is group discussion with 20 (twenty) youth participants from the Al-Kamilah Foundation, Depok. The output of this Community Service activity is in the form of publications on online media and one scientific article published through the Lokabmas Kreativ PKM Journal, Pamulang University. As well as increasing knowledge and understanding the basics of managing finances, generating the best potential from within and motivating participants to improve their own abilities in terms of leadership and communication in all aspects.
\end{abstract}

Keywords: Financial management, Organizational Management, Leadership, Communication

\begin{abstract}
Abstrak
Tujuan dari kegiatan Pengabdian Kepada masyarakat ini adalah untuk melaksanakan salah satu Tri Dharma Perguruan Tinggi. Selain itu adalah untuk untuk menumbuhkan kreativitas, kemandirian serta dapat memanajemen diri dan keuangan dengan baik dan lebih terarah bagi para remaja di Yayasan Al-Kamilah Depok dengan cara mengenalkan cara pengelolaan keuangan sederhana dan melakukan pelatihan manajemen organisasi, khususnya kepemimpinan dan komunikasi. Metode pelaksanaan kegiatan Pengabdian Kepada Masyarakat yang digunakan adalah penyuluhan, tanya jawab, diskusi dan juga berbagi pengalaman. Teknik dalam pelaksanaan kegiatan Pengabdian Kepada masyarakat yang digunakan adalah diskusi kelompok dengan jumlah peserta 20 (dua puluh) orang remaja dari Yayasan Al-Kamilah Depok. Adapun luaran dari kegiatan Pengabdian kepada Masyarakat ini berupa publikasi pada media online dan satu artikel ilmiah yang dipublikasikan melalui Jurnal Lokabmas Kreativ PKM Universitas Pamulang. Serta bertambahnya pengetahuan dan memahami dasar dalam mengelola keuangan, membangkitkan potensi terbaik dari dalam diri dan motivasi kepada peserta, untuk meningkatkan kemampuan diri sendiri dalam hal kepemimpinan dan komunikasi di semua aspek.
\end{abstract}

Kata kunci : Pengelolaan keuangan, Manajemen Organisasi, Kepemimpinan, Komunikasi 


\section{JURNAL ABDIMAS

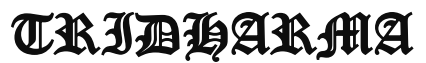 AtA:}

P-ISSN 2615-6849, E-ISSN 2716-070X

Jurnal ABDIMAS Vol. 2,No.3, Agustus 2021,Hal(86-95)

@ Prodi Manajemen Fakultas Ekonomi Universitas Pamulang

Email: abdimasjurnal.unpam@gmail.com Telp: (021) 741-2566

\section{PENDAHULUAN}

\section{Analisis Situasi Permasalahan}

Kemajuan teknologi dan pesatnya pembangunan mengakibatkan munculnya berbagai masalah, salah satunya adalah masalah konsumtif masyarakat Indonesia umumnya dan remaja pada khususnya. Perlu upaya untuk merubah perilaku remaja remaja yang konsumtif melalui pengelolaan keuangan sederhana dalam kehidupan sehari-hari. Merencanakan keuangan sejak dini wajib dilakukan oleh setiap masyarakat pada umumnya dan remaja pada khususnya. Dengan membuat rencana keuangan yang baik akan membantu untuk menggunakannya secara bijak sesuai dengan kebutuhan. Pengajaran pengelolaan keuangan yang diberikan kepada remaja berupa perbedaan antara kebutuhan dan keinginan, pengenalan terhadap konsep menabung, hingga edukasi tentang investasi masa depan.

Selain itu kecenderungan remaja yang tidak banyak aktif dalam organisasiorganisasi baik di lingkungan sekolah maupun lingkungan masyarakat dapat berdampak buruk untuk dirinya sendiri. Padahal skill dalam sebuah organisasi sangat di perlukan oleh remaja, di dalam organisasi remaja akan memperoleh softskill yang tidak didapatkan dalam kegiatan formal sekolah. Seperti, problem solving, public speaking dan juga berdiskusi. Organisasi juga memberikan para remaja kesempatan belajar bagaimana menjalin teamwork, yang nantinya sangat dibutuhkan ketika menghadapi dunia kerja. Begitu pula dengan pemahaman dalam berorganisasi, beroganisasi adalah kegiatan yang memiliki banyak manfaat bagi kehidupan manusia mengingat manusia adalah makhluk sosial yang tidak bisa hidup sendiri. Organisasi pada dasarnya merupakan suatu tempat di mana orangorang berkumpul, bekerja sama secara rasional, sistematis, terkendali, dan memanfaatkan sumber daya (dana, material, lingkungan, metode, sarana, prasarana, data) yang digunakan secara efisien dan efektif untuk mencapai tujuan bersama

Dari hasil pengamatan Yayasan $\mathrm{Al}$ Kamilah di dirikan di Jl. Rambutan Blok B2 No.8 RT 01/08 Komplek Taman Serua Kelurahan Serua Kecamatan Bojongsari Kota Depok Jawa Barat. Kelurahan Serua terletak di Kecamatan Bojongsari, Kota Depok memiliki banyak remaja yang membutuhkan penyuluhan mengenai pengelolaan keuangan sederhana dan juga dalam berorganisasi khususnya kemampuan kepemimpinan dan komunikasi.

\section{Rumusan Masalah}

Berdasarkan latar belakang diatas, penulis selaku dosen Universitas Pamulang melalui penyelenggaraan pengabdian kepada masyarakat bekerja secara koordinative dan integrative dengan remaja, serta pengimplementasian ilmu pengelolaan keuangan dan mananjemen organisasi pada dunia kerja. Oleh karena itu kami merumuskan masalah dalam pengabdian kepada masyarakat ini yaitu : penyuluhan pengelolaan keuangan sederhana dan pengenalan manajemen organisasi pada remaja di Yayasan Al Kamilah Bojongsari, Serua, Depok.

\section{Tujuan Pengabdian Kepada Masyarakat}

Adapun tujuan dari Pengabdian Kepada Masyarakat ini adalah untuk meningkatkan kemampuan pengelolaan keuangan sederhana pada remaja dengan cara mengenalkan konsep menabung dan investasi sederhana, meningkatkan kemampuan manajemen organisasi pada remaja dengan cara menumbuhkan jiwa kepemimpinan dan komunikasi pada remaja di Yayasan Al Kamilah Serua, Depok. 


\section{JURNAL ABDIMAS

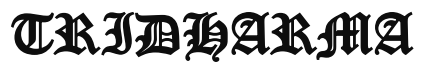 AtA:}

P-ISSN 2615-6849, E-ISSN 2716-070X

Jurnal ABDIMAS Vol. 2,No.3, Agustus 2021,Hal(86-95)

@ Prodi Manajemen Fakultas Ekonomi Universitas Pamulang

Email: abdimasjurnal.unpam@gmail.com Telp: (021) 741-2566

\section{Manfaat Pengabdian Kepada Masyarakat}

a. Secara Teoritis

Pengabdian ini diharapkan dapatkan memberikan sumbangan dalam aspek teoritis (keilmuan) yaitu dapat memberikan pemikiran, pengetahuan dan gambaran yang lebih jelas mengenai faktor-faktor fundamental dan sebagai aplikasi penerapan dalam ilmu manajemen.

b. Secara Praktis

Hasil pengabdian ini diharapkan dapat memberikan gambaran secara nyata dalam mengelola keuangan sederhana dan diharapkan dapat mengimplementasikan ilmu manajemen organasasi tentang kepemimpinan dan komunikasi bagi para remaja di Yayasan Al Kamilah Depok.

\section{TINJAUAN PUSTAKA}

\section{Definisi Penyuluhan}

Christoplos menyatakan bahwa penyuluh sebagai sebuah sistem yang memfasilitasi akses bagi masyarakat, kelompok, dan pelaku lainnya kepada pengetahuan, informasi dan teknologi, menghubungkan masyarakat dengan pihak penelitian, pendidikan, agribisnis, pemasaran dan institusi terkait lainnya, dan membantu mengembangkan teknik, organisasi dan kemampuan manajemen secara terampil dan praktis, (Rasmira, 2019). Sebagai proses komunikasi, penyuluhan berarti proses di mana seorang individu (komunikator) menyampaikan lambang-lambang tertentu, biasanya berbentuk verbal untuk mempengaruhi tingkah laku komunikan. Akhirnya, penyuluhan boleh ditujukan untuk kegiatan mempengaruhi orang lain. Penyuluhan merupakan suatu usaha menyebarluaskan hal-hal yang baru agar masyarakat tertarik, berminat dan bersedia untuk melaksanakannya dalam kehidupan mereka sehari-hari.

\section{Definisi Pengelolaan Keuangan}

Menurut Rizkiawati dan Asandimitra (2018) bahwa pengelolaan keuangan adalah kemampuan seseorang dalam merencanakan, menganggarkan, mengelola, mengendalikan, mencari, serta menyimpan dana keuangan sehari-hari yang dimiliki. Pengelolaan keuangan berkaitan dengan tanggung jawab keuangan seseorang terkait cara mengelola keuangan. Tanggung jawab dalam hal keuangan merupakan proses mengelola keuangan serta proses menguasai penggunaan aset keuangan, maupun aset-aset lain dengan produktif. Dalam pengelolaan keuangan yang baik terdapat komponen yang harus dipenuhi, yaitu : mengontrol pengeluaran, membayar tagihan tepat waktu, merencanakan keuangan untuk masa depan, menabung dan dapat mencukupi kebutuhan keluarga. Pengelolaan keuangan sebaiknya dilakukan untuk jangka pendek dan jangka panjang

\section{Definisi Manajemen Organisasi}

Menurut Malayu S. P. Hasibuan (2016 : 54) Manajemen adalah ilmu dan seni mengatur proses pemanfaatan sumber daya manusia dan sumber-sumber lainnya secara efektif dan efisien untuk mencapai suatu tujuan tertentu. Adapun pengertian organisasi menurut Siagian (2006 : 38) menjelaskan organisasi seperti berikut setiap bentuk persekutuan antara dua orang atau lebih yang bekerja bersama serta secara formal terikat dalam rangka pencapaian suatu tujuan yang telah ditentukan dalam ikatan yang terdapat seorang atau beberapa orang yang disebut atasan dan seorang atau sekelompok orang yang disebut bawahan. Manajemen organisasi adalah proses dalam membuat perencanaan, pengorganisasian, 


\section{JURNAL ABDIMAS

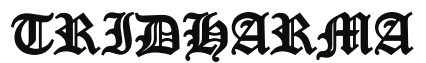

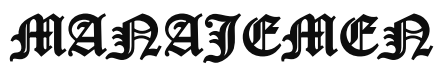

P-ISSN 2615-6849, E-ISSN 2716-070X

Jurnal ABDIMAS Vol. 2,No.3, Agustus 2021,Hal(86-95)

@ Prodi Manajemen Fakultas Ekonomi Universitas Pamulang

Email: abdimasjurnal.unpam@gmail.com Telp: (021) 741-2566 mengendalikan dan memimpin berbagai usaha dari anggota organisasi dan menggunakan semua sumber daya organisasi untuk mencapai sasaran yang sistematis untuk memadukan bagian-bagian yang saling tergantung menjadi suatu kesatuan yang utuh di mana kewenangan, koordinasi, dan pengawasan dilatih untuk mencapai tujuan yang telah ditentukan.

\section{Definisi Kepemimpinan}

Kepemimpinan adalah proses mempengaruhi orang lain dalam hubungan antara pimpinan dengan bawahan atau dengan pengikut. Kepemimpinan (Rifa'I : 2013) juga dapat dijelaskan sebagai seni dan ilmu tentang proses memperoleh tindakan dari orang lain dan pencapaian visi. Setiap orang menginginkan peminpin yang memiliki kompetensi, kejujuran, pandangan ke depan, pemberi inspirasi dan keberhasilan. Pemimpin adalah mereka yang menggunakan wewenang formal untuk mengorganisasikan, mengarahkan, mengontrol para bawahan yang bertanggung jawab, supaya semua bagian pekerjaan dikoordinasi demi mencapai tujuan perusahaan Inti kepemimpinan adalah proses mempengaruhi tindakan orang lain.

\section{Definisi Komunikasi}

Komunikasi menurut Effendy (2005 : 9) adalah untuk mencapai kesamaan makna antara manusia yang terlibat dalam komunikasi yang terjadi, dimana kesepahaman yang ada dalam benak komunikator (penyampai pesan) dengan komunikan (penerima pesan) mengenai pesan yang disampaikan haruslah sama agar apa yang komunikator maksud juga dapat dipahami dengan baik oleh komunikan sehingga komunikasi berjalan baik dan efektif. Komunikasi merupakan proses penyampaian simbol-simbol baik verbal maupun nonverbal. Maka dari itu komunikasi terbagi menjadi 2 bagian yaitu komunikasi verbal dan komunikasi nonverbal, komunikasi verbal adalah komunikasi yang terjadi secara langsung dengan lisan atau tulisan. Didalam kegiatan komunikasi, kita menempatkan kata verbal untuk menunjukan pesan yang dikirimkan atau yang diterima dalam bentuk kata-kata baik lisan maupun lisan.

\section{Definisi Remaja}

Remaja merupakan masa dimana peralihan dari masa anak-anak ke masa dewasa, yang telah meliputi semua perkembangan yang dialami sebagai persiapan memasuki masa dewasa. Perubahan perkembangan tersebut meliputi aspek fisik, psikis dan psikososial (Narendra, 2005). Masa remaja merupakan salah satu periode dari perkembangan manusia. Remaja ialah masa perubahan atau peralihan dari anak-anak ke masa dewasa yang meliputi perubahan biologis, perubahan psikologis, dan perubahan sosial (Sofia \& Adiyanti, 2013). Remaja lebih banyak menghabiskan waktunya bersama dengan teman-teman, maka pengaruh teman-teman sebaya pada sikap, pembicaraan, minat, penampilan, dan perilaku lebih besar dari pada pengaruh keluarga.

\section{MATERI DAN METODE PELAKSANAAN}

\section{Kerangka Pemecahan Masalah}

Persetujuan proposal pengabdian kepada masyarakat pada kampus Universitas Pamulang dan Yayasan $\mathrm{Al}$ Kamilah yang beralamat di Jl. Serua no 3, Serua, Kec. Bojongsari, Kota Depok dengan memberikan penyuluhan mengenai pengelolaan keuangan sederhana dan juga mengenalkan manajemen organisasi khususnya kemampuan kepemimpinan dan kemampuan komunikasi kepada para remaja, guna menambah pengetahuan, 


\section{JURNAL ABDIMAS

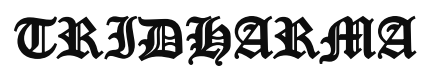

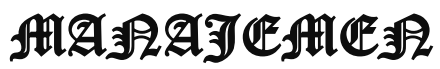

P-ISSN 2615-6849, E-ISSN 2716-070X

Jurnal ABDIMAS Vol. 2,No.3, Agustus 2021,Hal(86-95)

@Prodi Manajemen Fakultas Ekonomi Universitas Pamulang

Email: abdimasjurnal.unpam@gmail.com Telp: (021) 741-2566 keterampilan dan kemampuan dalam menghadapi masa dewasa yang akan datang.

\section{Realisasi Pemecahan Masalah}

Realisasi pemecahan masalah dilakukan dengan melakukan kegiatan persiapan-persiapan sebagai berikut :

1) Melakukan riset mengenai cara pengelolaan keuangan sederhana yang bisa digunakan oleh remaja dan peserta penyuluhan dalam mengelola keuangannya sehari-hari.

2) Melakukan riset tentang cara berorganisasi, bersikap kepemimpinan dan kemampuan komunikasi yang baik agar dapat di implementasikan pada remaja dan peserta penyuluhan.

3) Menentukan waktu pelaksanaan dan lamanya kegiatan pengabdian bersama-sama tim pelaksana

4) Menentukan dan mempersiapkan materi yang akan disampaikan dalam kegiatan Pengabdian Kepada Masyarakat.

5) Mengkoordinasikan dengan Pihak Rumah Pintar Tangerang Raya tentang waktu dan tema pengabdian kepada masyarakat sehingga dapat disosialisasikan kembali kepada para remaja dan atau peserta penyuluhan.

\section{Khalayak Sasaran}

Khalayak sasaran yang dipilih dalam Pengabdian Kepada masyarakat ini adalah para remaja yang belum mengerti mengenai pengelolaan keuangan sederhana dan membutuhkan pengetahuan mengenai manajemen organisasi di Yayasan Al Kamilah Bojongsari, Kota Depok, Jawa Barat, yang terdiri dari 20 orang remaja di Yayasan tersebut.

\section{Tempat dan Waktu}

a. Tempat Pengabdian
Pelaksanaan kegiatan pengabdian kepada masyarakat di Yayasan Al Kamilah Bojongsari yang beralamat di Jl. Serua Raya No.3, Kelurahan Serua, Kecamatan Bojongsari, Kota Depok, Jawa Barat, Kode Pos 16517.

b. Waktu Pengabdian

Pengabdian kepada Masyarakat dilaksanakan pada Hari Sabtu dan Minggu tanggal 03 - 04 April 2021, dilaksanakan dari pukul 13.00-17.00

\section{Metode Kegiatan}

Metode kegiatan Pengabdian Kepada Masyarakat yang digunakan dalam Pengabdian Kepada Mayarakat di Yayasan Al Kamilah adalah melakukan pemecahan masalah dengan cara penyuluhan, tanya jawab, diskusi dan berbagi pengalaman (sumbang saran).

\section{HASIL DAN PEMBAHASAN}

\section{Gambaran Umum}

Pelatihan dilaksanakan selama dua hari, pada tanggal 03 April 2021 dan 04 April 2021 dengan mengikuti protokol kesehatan yang di wajibkan pemerintah, dihadiri sebanyak 20 peserta remaja dari Yayasan Al Kamilah Bojongsari Serua Depok. Semua peserta mengikuti kegiatan secara penuh dikarenakan semua peserta antusias mengikuti kegiatan penyuluhan dan pelatihan. Dari respon (tanggapan peserta) yang diberikan sebanyak 15\% menyatakan bahwa kegiatan penyuluhan dengan topik ini tika perlu dilakukan, sedangkan sebanyak $85 \%$ merasa perlu dengan kegiatan penyuluhan ini, karena sangat membantu dalam pengelolaan keuangan yang benar dan mendukung proses pembentukan jiwa kepemimpinan dan kemampuan komunikasi yang baik.

Hasil dan Pembahasan 


\section{JURNAL ABDIMAS

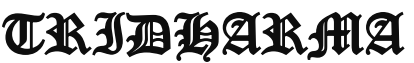

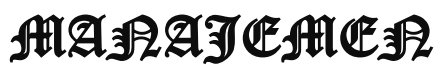

P-ISSN 2615-6849, E-ISSN 2716-070X

Jurnal ABDIMAS Vol. 2,No.3, Agustus 2021,Hal(86-95)

@ Prodi Manajemen Fakultas Ekonomi Universitas Pamulang

Email: abdimasjurnal.unpam@gmail.com Telp: (021) 741-2566
Berikut materi dalam penyuluhan pengelolaan keuangan sederhana dan pengenalan manajemen organisasi yang diberikan kepada remaja di Yayasan Al Kamilah Bojongsari Serua Depok.

Pada hari pertama tanggal 03 April 2021 di jelaskan oleh narasumber pengabdian mengenai cara mengatur keuangan sejak remaja karena keterampilan tersebut bisa membantu remaja di masa yang akan datang. Perilaku boros remaja selayaknya diubah. Dengan mengatur keuangan, para remaja bisa hidup lebih hemat. Pengelolaan uang bisa diterapkan dalam kehidupan sehari-hari. Pembelajaran itu bisa dimulai dengan pembagian penggunaan uang saku atau pemasukan lainnya. Dari situ remaja harus bisa memanfaatkannya dengan baik dan tidak kekurangan dalam memenuhi kebutuhan.
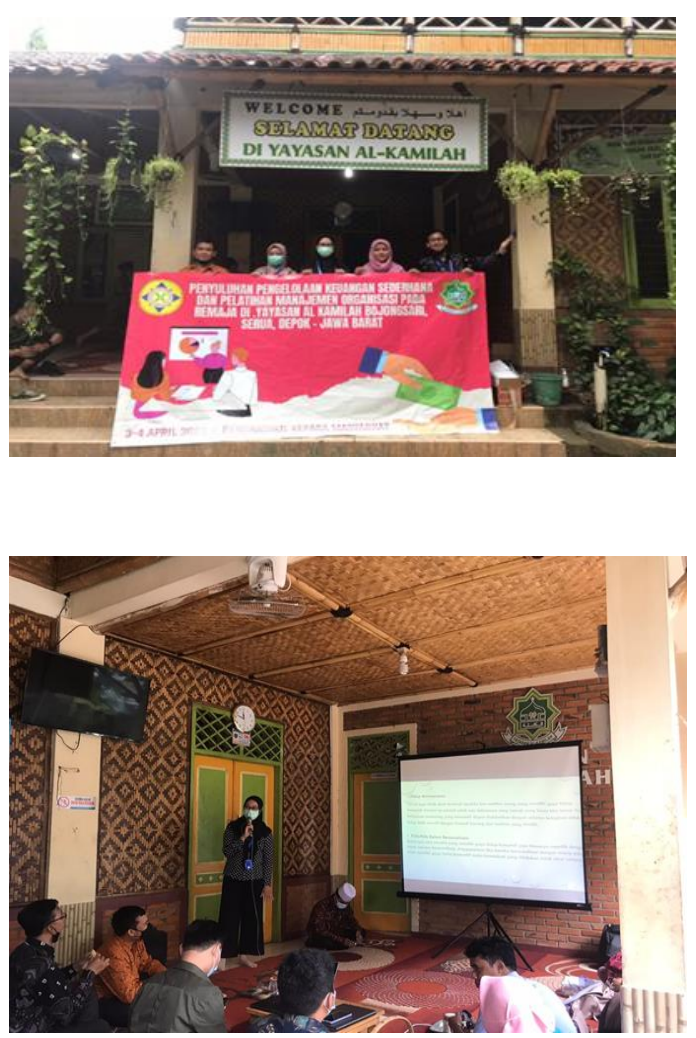

Berikut cara agar remaja bisa memaksimalkan penggunaan uang saku dengan baik:

1. Catat semua pemasukan dan pengeluaran sehari-hari.

Cara mengatur keuangan yang paling cerdas adalah dengan selalu menulis dan mencatat pemasukan serta pengeluaran setiap bulannya. Tujuannya adalah agar di bulan berikutnya kita bisa mengurangi pengeluaran yang sekiranya tidak begitu penting.

2. Gunakan sesuai kebutuhan.

Menggunakan uang tersebut untuk memenuhi kebutuhan bukan keinginan. Selalu menahan diri agar tidak membeli barang sesuai keinginan tapi membeli barang sesuai kebutuhan.

3. Berusaha hidup hemat.

Membeli barang dengan harga yang lebih rendah dan jangan cepat bosan dengan model barang. Usahakan kita jangan gampang tergoda dengan trend pakaian atau yang lainnya, dan itu hanya membuat kita boros dan keuangan akan perlahan-lahan habis.

4. Berusaha untuk menabung.

Menyisihkan sebagian uang saku untuk ditabung. Cobalah untuk menabung di bank atau koperasi. Karena apabila di taruh di bank uang tersebut akan aman alias tidak berkurang banyak. Hal ini juga bisa membantu kita untuk mengeola uang agar tidak boros.

5. Mencoba berjualan.

Buat para remaja yang ingin mendapat uang tambahan bisa mencoba berjualan. Barang jualannya pun bisa 


\section{JURNAL ABDIMAS

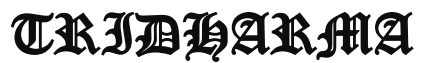

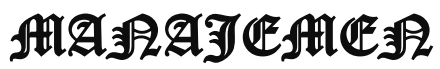

P-ISSN 2615-6849, E-ISSN 2716-070X

Jurnal ABDIMAS Vol. 2,No.3, Agustus 2021,Hal(86-95)

@ Prodi Manajemen Fakultas Ekonomi Universitas Pamulang

Email: abdimasjurnal.unpam@gmail.com Telp: (021) 741-2566 pulsa, makanan ringan atau nasi yang dititipkan di kantin dan bisa berjualan online. Selain bisa mengelola keuangan juga bisa menumbuhkan sifat wirausaha yang bisa bermanfaat untuk masa..

Jika para remaja sudah bisa mengatur keuangannya dengan baik, maka akan memberi keuntungan baginya di masa sekarang atau masa depan. Adapun keuntungan itu meliputi:

1. Di masa yang akan datang remaja akan bisa mengatur keuangannya dengan baik

2. Memiliki perencanaan masa depan yang lebih baik

3. Terbisa menabung

4. Melindungi diri dari kejadian yang tak terduga

5. Bisa melatih hidup hemat

6. Menjadi pribadi yang mandiri

7. Bisa menjadi wirausaha sukses.

Dilanjutkan pada hari kedua, pelaksanaan di lakukan pada tanggal 04 April 2021 diberikan penjelasan oleh narasumber mengenai pengenalan manajemen organisasi.

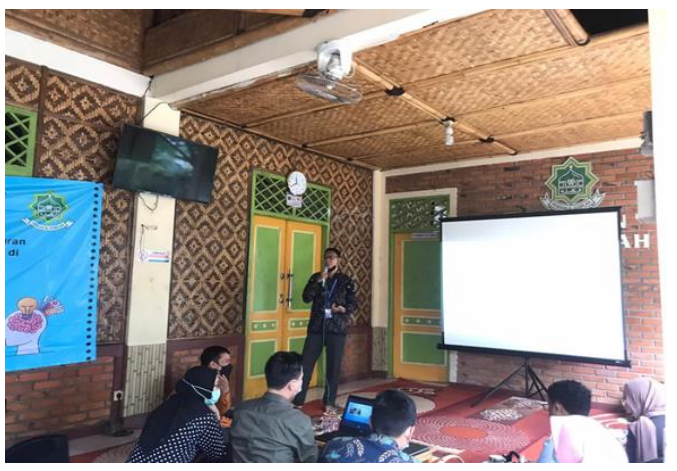

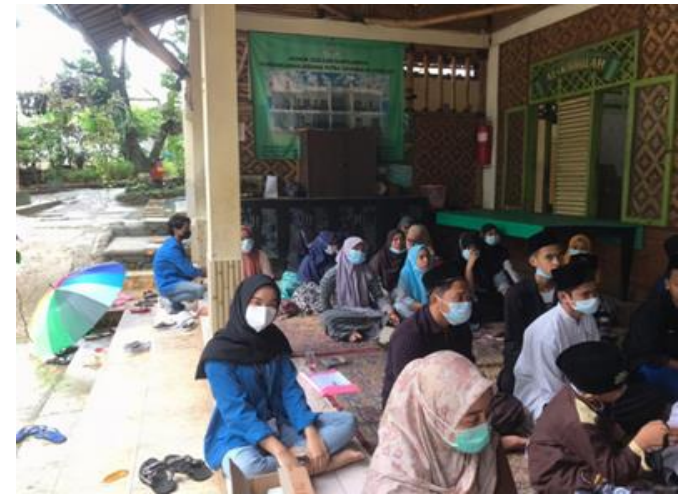

Adapun beberapa kemampuan berorganisasi yang penting dikuasai oleh remaja diantaranya adalah :

1. Kepemimpinan (Leadership)

Pada dasarnya setiap anak memiliki potensi menjadi seorang pemimpin. Maka dari itu, keterampilan memimpin pada anak harus diterapkan sejak dini sebagai landasan yang kokoh untuk mewujudkan mimpi serta tujuan hidupnya. Jiwa kepemimpinan pada anak dapat melatih rasa tanggung jawab, disiplin, dan ketekunan yang bermanfaat untuk masa depan anak

2. Kerjasama (Teamwork)

Soft skill selanjutnya yang harus dimiliki oleh seorang remaja muda adalah kemampuan kerja sama. Menjadi seseorang yang bisa diajak bekerja sama di dalam organisasi sangat penting untuk masa depan. Banyak orang yang mampu bekerja sangat baik jika bekerja sendiri, tapi kesulitan ketika harus bekerja sama.

3. Komunikasi (Communication)

Cara mendapatkan soft skill ini dapat kamu mulai dari menjadi pendengar yang baik. Ketika seseorang mendengarkan orang lain bicara. 


\section{JURNAL ABDIMAS

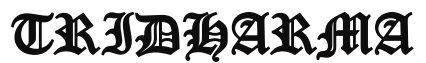

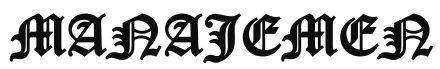

P-ISSN 2615-6849, E-ISSN 2716-070X

Jurnal ABDIMAS Vol. 2,No.3, Agustus 2021,Hal(86-95)

@Prodi Manajemen Fakultas Ekonomi Universitas Pamulang

Email: abdimasjurnal.unpam@gmail.com Telp: (021) 741-2566

\section{Berpikir Kritis}

Cara untuk melatih soft skill yang satu ini dengan dua hal, yaitu membaca buku serta melakukan debat dan diskusi. Kedua kegiatan ini sangat membantu dalam mengembangkan soft skill berpikir kritis. Membaca dapat membantumu mengenal lebih banyak kosa kata, membuka wawasan, dan juga memperdalam pembelajaran tentang berbagai topik. Selain itu, kemampuan ini juga bisa diasah dengan sering melakukan debat dan diskusi, dengan cara melakukannya bersama keluarga, teman, maupun rekan kerja.

\section{KESIMPULAN DAN SARAN}

\section{Kesimpulan}

Pelaksanaan kegiatan pengabdian kepada masyarakat oleh Lembaga Penelitian dan Pengabdian Masyarakat (LPPM) Universitas Pamulang yang dilakukan oleh dosen-dosen program studi manajemen telah berjalan dengan lancar dan mendapat sambutan hangat dari tempat pelaksanaan kegiatan ini yaitu Yayasan Al Kamilah di Jl. Serua Raya, Kelurahan Serua, Kecamatan Bojongsari, Kota Depok jawa Barat.

Dari kegiatan Pengabdian Kepada Masyarakat ini dapat disimpulkan bahwa :

a. Pengetahuan pengelolaan keuangan sederhana para remaja peserta pengabdian di Yayasan Al Kamilah Bojongsari Depok menjadi bertambah.

b. Penting untuk mengendalikan perilaku konsumtif tidak jelas tujuannya. Dengan demikian diperlukan adanya skala prioritas pembelanjaan atau pengeluaran keuangan bagi remaja. c. Kemampuan para remaja peserta pengabdian di Yayasan Al Kamilah Bojongsari Depok dalam hal menumbuhkan jiwa kepemimpinan dan komunikasi yang baik dan efektif semakin meningkat.

\section{Saran}

Harapan kami dengan pengabdian ini dapat menambah pemahaman dan wawasan tentang ilmu manajemen khususnya mengenai pengelolaan keuangan sederhana dan manajemen organisasi.

Mengingat besarnya manfaat kegiatan Pengabdian Kepada Masyarakat ini maka selanjutnya perlu :

a. Mengadakan penyuluhan dan pelatihan serupa kepada masyarakat di daerah lain.

b. Adanya kesinambungan program pasca kegiatan pengabdian ini, sehingga para remaja di Yayasan Al Kamilah Bojongsari Serua dapat mempraktekkan dan mengelola keuangan serta bisa meningkatkan kemampuan komunikasi dan kepemimpinan, agar dapat meningkatkan potensi yang ada.

\section{DAFTAR PUSTAKA}

Agus Harjito, Martono. 2008. Manajemen Keuangan, edisi 1. Yogyakarta: EKONISIA.

Efendy, Onong Uchana. 2005. Ilmu Komunikasi Teori dan Praktek. Bandung:Remaja Rosda Effendy, Onong Uchjana. 2008. Dinamika Komunikasi. Bandung : Remaja Rosdakarya.

Effendy, Onong Ucjhana. 2001. Ilmu Komunikasi Teori dan Praktek. Bandung: PT. Remaja Rosdakarya.

Hasibuan, Malayu S.P. 2016. Manajemen Sumber Daya Manusia. Edisi 


\section{JURNAL ABDIMAS

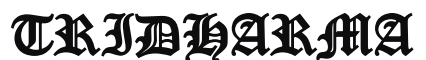

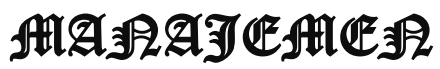

P-ISSN 2615-6849, E-ISSN 2716-070X

Jurnal ABDIMAS Vol. 2,No.3, Agustus 2021,Hal(86-95)

@ Prodi Manajemen Fakultas Ekonomi Universitas Pamulang

Email: abdimasjurnal.unpam@gmail.com Telp: (021) 741-2566
Revisi. Jakarta: Penerbit PT Bumi Aksara.

I Made Sudana. 2011. Manajemen Keuangan Perusahaan Teori dan Praktik. Jakarta: Erlangga

Indah Listiana, Sumardjo, Dwi Sadono, dan Prabowo Tjiptopranoto. 2018. Hubungan Kapasitas Penyuluh dengan Kepuasan Petani dalam Kegiatan Penyuluhan. Jurnal Penyuluhan. Vol. 14 No. 2.

King, L. A. 2012. Psikologi Umum : Sebuah Pandangan Apresiatif Buku 2. Jakarta: Salemba Humanika.

Listiani, Kurnia. 2017. Pengaruh Financial Knowledge, Locus Of Control Dan Financial Attitude Terhadap Financial Management Behavior Pada Mahasiswa. Undergraduate thesis, STIE PERBANAS SURABAYA.

Manz, Charles.C dan Henry P.Sims, Jr. 2001. The New Super Leadership. San Franc isco: Berret dan Koehler.

Mönks, F.J., Knoers, A.M.P., \& Haditono, S.R. 2008. Psikologi Perkembangan: Pengantar dalam Berbagai Bagiannya. Yogyakarta: Gadjah Mada University Press.

Narendra, M.B. 2005. Tumbuh Kembang Anak dan Remaja. Jakarta : Sagung Seto.

Nur Laili Rizkiawati, Nadia Asandimitra Haryono. 2018. Pengaruh Demografi, Financial Knowledge, Financial Attitude, Locus Of Control Dan Financial SelfEfficacy Terhadap Financial
Management Behavior Masyarakat Surabaya, jurnal ilmu manajemen, Volume 6 Nomor 3.

Pasaribu, V. L. D., Agrasadya, A., Shabrina, N., \& Krisnaldy, K. (2020). Menjadi Enterpreneur Muda Yang Memiliki Jiwa Leadership Untuk Menghadapi Masa Depan. Abdi Laksana: Jurnal Pengabdian Kepada Masyarakat, 1(1).

Pasaribu, V. L. D., Susanti, F., \& Hartuti, E. T. K. (2019). Memotivasi Siswa dan Siswi SMK Letris Indonesia di Dalam Menentukan Pilihan Untuk Melanjutkan Pendidikan Atau Bekerja Setelah Lulus Sekolah. Jurnal Pengabdian Dharma Laksana, 1(2), 161-172.

Pasaribu, V. L. D., Sulaiman, S., Sutiman, S., Thaharudin, T., \& Purnomo, B. Y. (2020). Pengenalan Letak Posyandu Terdekat Dikelurahan Pisangan Dengan Manajemen Pemasaran Revolusi 4.0 Untuk Meningkatkan Pengetahuan Masyarakat Letak Dan Fungsi Posyandu Terdekat Pada Kelurahan Pisangan. Dedikasi Pkm, 1(1), 105-110.

Pasaribu, V. L. D., Oktrima, B., Prabowo, B., Arianto, N., \& Haryoko, U. B. (2020). Progam Pendampingan Dan Penyelenggaraan Pendidikan Anak Pada Usia Dini Terhadap Prestasi Belajar Dilingkungan Rt 020 Rw 009. Kel Giri Peni. Kec Wates. Yogyakarta. Jurnal Lokabmas Kreatif, 1(1), 71-75.

Pasaribu, V. L. D., Jannah, M., Fazar, M., 


\section{JURNAL ABDIMAS

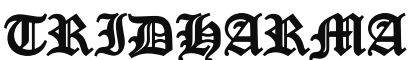

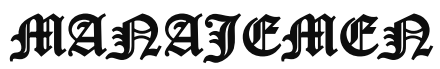

P-ISSN 2615-6849, E-ISSN 2716-070X

Jurnal ABDIMAS Vol. 2,No.3, Agustus 2021,Hal(86-95)

@ Prodi Manajemen Fakultas Ekonomi Universitas Pamulang

Email: abdimasjurnal.unpam@gmail.com Telp: (021) 741-2566
Putra, S. P., Monalisa, M., \& Sofa, M. (2021). MENINGKATKAN PRODUKTIVITAS USAHA DIMASA PANDEMI PADA IBU PKK RT 004/003 KELURAHAN SAWAH BARU CIPUTAT, TANGERANG SELATAN. Abdi Laksana: Jurnal Pengabdian Kepada Masyarakat, 2(2), 295301.

Pasaribu, V. L. D., Yuniati, H. L., Pranata, R., Sembayu, R., Purba, S. M., \& Nurbayani, T. T. A. (2021). MANAJEMEN KEUANGAN UNTUK MENGHADAPI DAN BERTAHAN DI ERA COVID 19. Jurnal Abdimas Tri Dharma Manajemen, 2(2), 12-18.

Pasaribu, V. L. D., Dwiyatni, A., Sabina, C., Ridwan, M., Gunawan, D. D., \& Noviani, B. C. (2021). EVALUASI PENERAPAN 3M DIMASA PANDEMIC COVID 19. Jurnal Abdimas Tri Dharma Manajemen, 2(2), 54-60.

Pasaribu, V. L. D., Syafei, A. N., Farhan, A., Aufaizah, A., Irani, C., \& Firtiayani, S. R. (2021). PENGARUH DISPLIN PROTOKOL KESEHATAN TERHADAP PENCEGAHAN PENULARAN VIRUS COVID19. Jurnal Abdimas Tri Dharma Manajemen, 2(2), 91-98.

Pasaribu, V. L. D., Septiani, F., Rahayu, S., Lismiatun, L., Arief, M., Juanda, A., ... \& Rahim, R. (2021). Forecast Analysis of Gross Regional Domestic Product based on the Linear Regression Algorithm Technique.
Priadi, A., Pasaribu, V. L. D., Virby, S., Sairin, S., \& Wardani, W. G. (2020). Penguatan Ekonomi Kreatif Berbasis Sumber Daya Desa Dikelurahan Rempoa. Abdi Laksana: Jurnal Pengabdian Kepada Masyarakat, 1(3), 356-35

Pradiani, Theresia. 2018. Pengaruh Sistem Pemasaran Digital Marketing Terhadap Peningkatan Volume Penjualan Hasil Industri Rumahan. Malang: Jurnal Ilmiah Bisnis dan Ekonomi Asia Vol. 11 No. 2.

R.Terry, George. 2006. Prinsip- Prinsip Manajemen. Jakarta: Bumi Aksara.

Rasmira, Djuara P. Lubis,dan Dyah Gandasari. 2019. Literasi Informasi Penyuluh Pertanian di Kabupaten Cianjur, Jurnal Penyuluhan. Vol. 15 No. 2.

Rifa,I Muhammad dan Fadhli Muhammad. 2013. Manajemen Organisasi. Bandung : Citapustaka Media Perintis.

Saparini, Dewi, G2b215006. 2017. Pengaruh Penyuluhan Tentang Hipertensi Terhadap Tingkat Kecukupan Kalium, Natrium, Cairan Dan Tekanan Darah Pada Penderita Hipertensi Peserta Prolanis Bina Sehat Di Puskesmas Pringsurat Kabupaten Temanggung. Undergraduate Thesis, Muhammadiyah University Of Semarang.

Subejo. 2010. Penyuluhan Pertanian Terjemahan Dari Agriculture, edisi 2. Jakarta. Extention. 


\section{JURNAL ABDIMAS

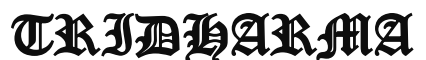

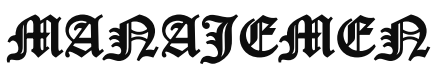

P-ISSN 2615-6849, E-ISSN 2716-070X

Jurnal ABDIMAS Vol. 2,No.3, Agustus 2021,Hal(86-95)

@ Prodi Manajemen Fakultas Ekonomi Universitas Pamulang

Email: abdimasjurnal.unpam@gmail.com Telp: (021) 741-2566
Siagian, Sondang. P. 2006. Filsafat Administrasi. Edisi revisi. Jakarta; Bumi Aksara.

Soetjiningsih. 2010. Tumbuh Kembang Remaja dan Permasalahannya. Jakarta :SagungSeto.

Sofia, Ari Dan Adiyati, Maria Goyetti. 2013. Hubungan Pola Asuh Otoritatif Orang Tua Dan Konformitas Teman Sebaya Terhadap Kecerdasan Moral, Jurnal Pendidikan Progresif, Volume 4 No 2.

\section{FOTO KEGIATAN PENGABDIAN KEPADA MASYARAKAT DI YAYASAN AL KAMILAH BOJONGSARI DEPOK}

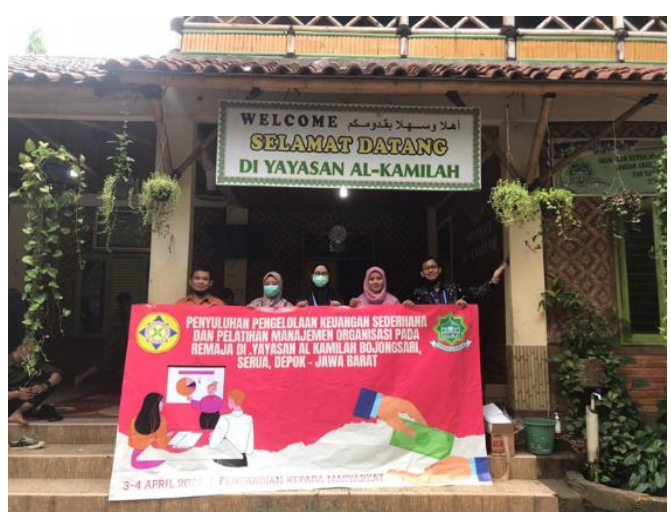

Foto 1. Foto bersama dengan para dosen setelah kegiatan Pengabdian Kepada Masyarakat.

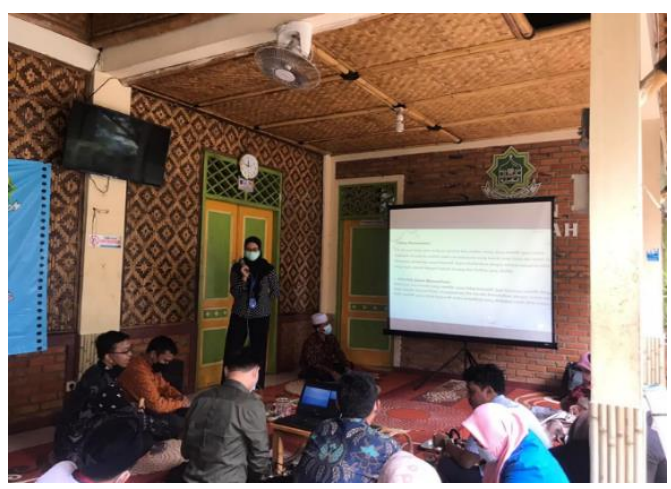

Foto 2. Penyuluhan Pengelolaan Keuangan Sederhana, Mengenalkan Konsep Pemasukan Dan Pengeluaran Uang oleh Ketua PKM, Ibu Ananda Hadistia, S.E., M.M.

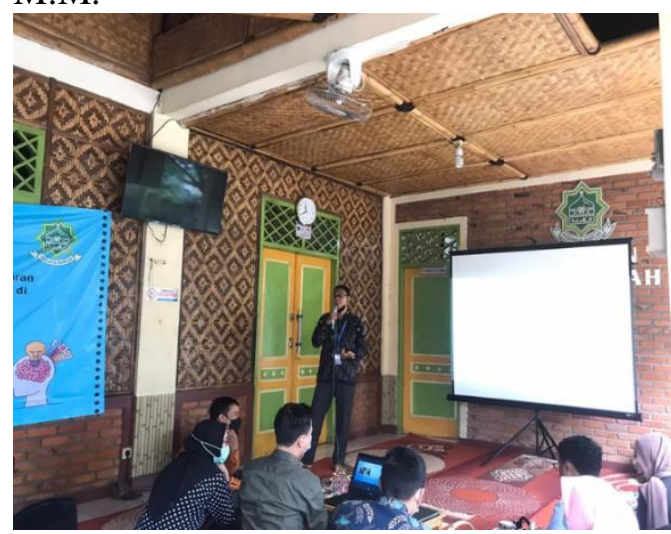

Foto 3. Pelatihan Manajemen Organisasi Khususnya Mengenai Kepemimpinan Dan Komunikasi yang diwakilkan oleh Bapak Ardi Bachtiar, S.E., M.M.

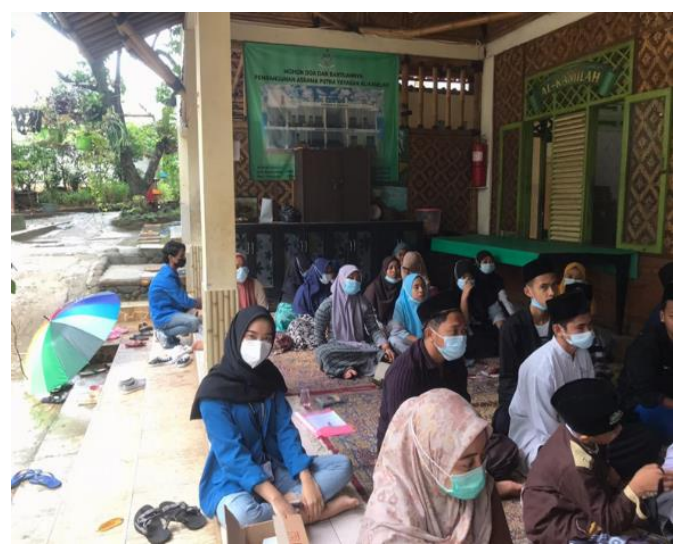

Foto 4. Kegiatan penyampaian materi yang diikuti oleh remaja peserta Pengabdian Kepada Masyarakat. 